\title{
A ROLE FOR BOMBESIN IN SENSORY PROCESSING IN THE SPINAL CORD $^{1}$
}

\author{
THOMAS L. O’DONOHUE, ${ }^{2}$ V. JOHN MASSARI, ${ }^{*}$ CHRISTOPHER J. PAZOLES, $\ddagger$ \\ BIBIE M. CHRONWALL, CLIFFORD W. SHULTS, REMI QUIRION, THOMAS N. CHASE, AND \\ TERRY W. MOODY§
}

\begin{abstract}
Experimental Therapeutics Branch, National Institute of Neurological and Communicative Disorders and Stroke, Bethesda, Maryland 20205; * Department of Pharmacology, Howard University, Washington, D. C. 20059; $\ddagger$ Central Research Division, Pfizer, Inc., Groton, Connecticut, 06340; and § Department of Biochemistry, George Washington University, Washington, D. C. 20037
\end{abstract}

Received November 11, 1983; Revised May 4, 1984; Accepted May 16, 1984

\begin{abstract}
Bombesin (BN)-containing neuronal processes were demonstrated in laminae I and II of the dorsal horn of the cat, rat, and mouse spinal cord by immunocytochemistry and radioimmunoassay. Dorsal rhizotomy in the cat resulted in a marked decrease in $\mathrm{BN}$ immunoreactivity in the dorsal horn indicating that $\mathrm{BN}$ is contained in primary sensory afferents. BN-binding sites were also localized in superficial laminae of the dorsal horn. The presence of both $\mathrm{BN}$ and $\mathrm{BN}$-binding sites in the dorsal horn suggested that $\mathrm{BN}$ may be involved in sensory processing in the spinal cord. Consistent with this hypothesis, it was demonstrated that an injection of BN into the spinal cord caused a biting and scratching response indicative of sensory stimulation. The effect was similar to that observed after injection of substance $\mathrm{P}$ into the cord with the exception that the BN effect lasted about 100 times longer than that induced by substance P. Taken together, these data indicate that BN may be a neurotransmitter of primary sensory afferents to the spinal cord.
\end{abstract}

Bombesin (BN) is a tetradecapeptide amide originally isolated and sequenced from the skin of the frog Bombina bombina. More recently, however, BN immunoreactivity has been identified in the mammalian central nervous system (Brown et al., 1978; Moody and Pert, 1979; Walsh et al., 1979; Moody et al., 1980, 1981a, c; Roth et al., 1982), sympathetic nervous system (Schultzberg, 1983), gastrointestinal tract (Polak et al., 1976; Dockray et al., 1979; Walsh et al., 1979; Buffa et al., 1982; Furness et al., 1982), human fetal lung (Wharton et al., 1978; Track and Cutz, 1982; Tsutsumi et al., 1983), adult lung (Cutz et al., 1981; Polak and Bloom, 1982; Track and Cutz, 1982; Tsutsumi et al., 1983), and oat cell carcinoma of the lung (Wood et al., 1981, Erisman et al., 1982; Sorensen et al., 1982; Moody et al., 1981b, 1983; Tsutsumi et al., 1983). The precise structure of mammalian $\mathrm{BN}$ is currently unknown, but it has been suggested that the mammalian form of $\mathrm{BN}$ may be gastrinreleasing peptide (GRP), a recently identified peptide that has structural and biological similarities to BN (McDonald et al., 1979, 1983; Brown et al., 1980; Erspamer et al., 1981; Yanaihara

\footnotetext{
${ }^{1}$ We thank Drs. F. Cuttitta and J. Minna at NCI for providing the bombesin antiserum and Dr. Robert $\mathrm{T}$. Jensen for helpful comments on an early draft of this manuscript. We also thank Mr. John F. Bishop for expert technical assistance, Ms. Donna Young for secretarial aid, and Mr. Farl Henderson and Mrs. Muriel Branford for assistance with surgical procedures. This research was supported in part by Grant BN27923451 from the National Science Foundation to V. J. M. and Grant NS17073 from the National Institutes of Health to T. W. M.

${ }^{2}$ To whom correspondence should be addressed.
}

et al., 1981), or neuromedin B, a recently identified BN-like peptide (Minamino et al., 1983).

Although the function of $\mathrm{BN}$ in anurans is largely unknown, a number of pharmacological actions have been identified in mammals. Peripheral actions of BN include stimulatory effects on gut and uterine smooth muscle contraction (Bertaccini et al., 1974a, b; Caprilli et al., 1975; Barthio et al., 1982; Davison, 1983), stimulation of release of gastrin and cholecystokinin from gut (Bertacinni et al., 1974a, b; Erspamer et al., 1974; Hirschowitz and Molina, 1983), growth hormone from the pituitary gland (Bicknell and Chapman, 1983), amylase and trypsinogen from the pancreas (Jensen et al., 1978; Andriulli et al., 1983), and also induction of tumor growth (Rosengurt and Sinnett-Smith, 1983). Central pharmacological actions of $\mathrm{BN}$ which have been reported are modulation of anterior pituitary hormone release (Rivier et al., 1978; Tache et al., 1979; Westendorf and Schonbrunn, 1982); inhibition of gastric acid release and stimulation of gastric mucus secretion (Tache et al., 1981; Tache, 1982; Tache and Collu, 1982); stimulation of neuronal electrical activity (Phillis and Limacher, 1974; Phillis and Kirkpatrick, 1979; Suzue et al., 1981; Tartara et al., 1982); stimulation of sympathetic outflow (Tache and Brown, 1982); and induction of analgesia (Pert et al., 1980), hyperglycemia (Brown and Vale, 1976; Brown et al., 1979), poikilothermia (Brown et al., 1977; Pittman et al., 1980; Tache et al., 1980), and a stereotypic scratching behavior (Brown et al., 1977). BN may also induce a number of pharmacological effects by both peripheral and central actions. The best examples of this are the central and peripheral actions of $\mathrm{BN}$ on induction of satiety (Gibbs et al., 1979; Martin and Gibbs, 1980; Baile and Della- 
Ferra, 1981; Gibbs and Fauser, 1981; Morley and Levine, 1981; Smith et al., 1981; Stein and Woods, 1981; Kulkosky et al., 1982; West et al., 1982; Hsaio and Spencer, 1983) and gastric emptying (Tepperman and Evered, 1980; Tache and Brown, 1982; Hsaio and Spencer, 1983).

Recent results have demonstrated that, within the central nervous system, the dorsal horn of the spinal cord has relatively high concentrations of BN-immunoreactive peptides (Moody et al., 1981c; Massari et al., 1983). The fact that some of the $\mathrm{BN}$ in the dorsal horn is derived from primary sensory afferents (Fuxe et al., 1983; Massari et al., 1983; Panula et al., 1983) suggested the possibility that $\mathrm{BN}$ may play a role in the transmission of sensory information to the central nervous system. Alternatively, other sources of BN to the dorsal horn might modulate neural transmission of primary sensory afferents. In the present study, we investigated the physiology and anatomy of $\mathrm{BN}$ and $\mathrm{BN}$ receptors in the spinal cord. It was found that $\mathrm{BN}$ and $\mathrm{BN}$ receptors were localized in superficial laminae of the dorsal horn of the spinal cord and that microinjection of $\mathrm{BN}$ into the cord induced a vigorous scratching response indicative of sensory stimulation.

\section{Materials and Methods}

Dorsal rhizotomy. Dorsal rhizotomy was performed 10 days before cats were sacrificed, essentially as described previously (Massari et al., 1983). Three cats were anesthetized with pentobarbital $(35 \mathrm{mg} / \mathrm{kg})$ and operated on using sterile procedures. The dorsal roots of Ll through S3 were exposed by performing a hemilaminectomy on the right lumbosacral vertebrae. The dorsal roots were cut extradurally using a small pair of dissecting scissors under a dissecting microscope, taking care to leave the dorsal radicular arteries and ventral root intact. The area was then gently packed in Gelfoam and sutured in layers. All cats received 600,000 units of Bicillin, injected intramuscularly, postoperatively.

Radioimmunoassay. Spinal cords from unoperated cats, rats, and mice were removed and frozen on dry ice and stored at $-70^{\circ} \mathrm{C}$. Cervical spinal cord slices of 300 to $500 \mu \mathrm{m}$ in thickness were cut in a cryostat at $-10^{\circ} \mathrm{C}$. Sections were then microdissected as described previously (Moody et al., 1981a, c; Massari et al., 1983). Samples were dissected into $2 \mathrm{~N}$ acetic acid on ice. The acidified tissues were boiled for $10 \mathrm{~min}$ and homogenized by sonication using a Kontes cell disrupter. An aliquot was removed for protein determination (Lowry et al., 1951).

BN immunoreactivity was measured as described previously (Moody et al., 1983). Homogenates were centrifuged at $10,000 \times \mathrm{g}$ for $10 \mathrm{~min}$, and the supernatants were removed and dried by vacuum centrifugation (Savant Inc, Hicksville, NY). The samples were resuspended in radioimmunoassay (RIA) buffer which consisted of phosphate-buffered saline (PBS), pH 7.4, containing $0.25 \%$ bovine serum albumin. A rabbit anti-BN serum at 1:100,000 dilution was incubated with sample or standard for $1 \mathrm{hr}$ at $4^{\circ} \mathrm{C}$. Then $5,000 \mathrm{cpm}$ (about $4 \mathrm{fmol}$ ) of $\left.{ }^{125} \mathrm{I}^{12} \mathrm{Tyr}^{4}\right]$ $\mathrm{BN}$ were added, and the solution was incubated for $16 \mathrm{hr}$ at $4^{\circ} \mathrm{C}$; the total volume was $0.4 \mathrm{ml}$. After incubation, $200 \mu \mathrm{l}$ of normal rabbit serum were added at 1:200 dilution followed by $100 \mu \mathrm{l}$ of goat antirabbit serum at 1:20 dilution. After $30 \mathrm{~min}, 200 \mu \mathrm{l}$ of $12 \%$ polyethylene glycol were added to enhance precipitation, and the samples were centrifuged at $1,000 \times g$ for $20 \mathrm{~min}$. The supernatant was removed and the pellet was counted for radioactivity in an LKB gamma counter (LKB Instruments, Inc., Gaithersburg, MD).

Immunocytochemistry. Rats and mice were anesthetized and perfused through the ascending aorta with ice-cold PBS containing $0.5 \%$ sodium nitrite followed by 200 to $300 \mathrm{ml}$ of ice cold $4 \%$ formaldehyde in PBS, $\mathrm{pH}$ 7.4. Normal and operated cats were anesthetized and perfused through the abdominal aorta according to the method of Loren et al. (1980) using $2 \%$ glyoxylic acid in the preperfusion buffer and $2 \%$ paraformaldehyde in the perfusion buffer. The spinal cords were rapidly removed, cut into $3.0-\mathrm{mm}$ sections, and postfixed for $30 \mathrm{~min}$ in the same fixative. The tissue slices were rinsed for $48 \mathrm{hr}$ in PBS containg $20 \%$ sucrose $(\mathrm{w} / \mathrm{v})$, frozen on dry ice, cut into $20-\mu \mathrm{m}$ coronal sections in a cryostat, mounted on chrome-alum-coated slides, and processed for the indirect immunohistochemical procedure of Coons (1958). The antibody used was a monoclonal antibody generated in mice. Sections were incubated overnight in the BN antibody diluted $1: 1000$ in PBS containing $0.3 \%$ Triton $\mathrm{X}-100(\mathrm{v} / \mathrm{v})$. The sections were washed three times for $5 \mathrm{~min}$ each in PBS with $0.3 \%$ Triton $\mathrm{X}-100$ and then incubated for $30 \mathrm{~min}$ in fluorescein isothiocyanate-conjugated goat anti-mouse IgG (N. L. Cappel Laboratories, Cochranville, PA), diluted 1:300 in PBS with $0.3 \%$ Triton X-100. The sections were washed three times for 5 min each, rinsed in PBS, and mounted in Gelvatol (Monsanto Chemical Co., Indian Orchard, MA). Sections were examined under a Leitz Orthoplan fluorescence microscope equipped with a Ploem illuminator. Preabsorption of BN antisera overnight with synthetic BN eliminated all staining, whereas preabsorption with substance $\mathrm{P}$ (SP) had no effect (peptides from Peninsula Laboratories, San Carlos, CA).

Autoradiography. Frozen, unfixed spinal cords from rats, cats, and mice were cut into $20-\mu \mathrm{m}$ sections in a cryostat at $-20^{\circ} \mathrm{C}$ and mounted on chrome-alum-coated slides. BN autoradiography was performed as described prevously (Wolf et al., 1983). Briefly, slides were incubated in a buffer composed of $10 \mathrm{~mm}$ HEPES, pH 7.4, $130 \mathrm{~mm} \mathrm{NaCl}, 4.7 \mathrm{~mm}$ $\mathrm{KCl}, 5 \mathrm{mM} \mathrm{MgCl} \mathrm{m}_{2}, 1 \mathrm{mM}$ EGTA, $0.1 \%$ bovine serum albumin, $0.07 \mathrm{mM}$ bacitracin, and $3 \mathrm{nM}\left[{ }^{125} \mathrm{I}-\mathrm{Tyr}^{4}\right] \mathrm{BN}$ in the presence or absence of $1 \mu \mathrm{M}$ unlabeled $\mathrm{BN}$. Incubations were performed for $60 \mathrm{~min}$ at $22^{\circ} \mathrm{C}$, followed by two consecutive 4 -min washes in buffer at $4^{\circ} \mathrm{C}$. Slices then were either counted by scraping into test tubes and assaying radioactivity in a Micromedic gamma counter or prepared for autoradiography using tritium-sensitive film (Ultrofilm, LKB) as described previously (Quirion et al., 1983). The exposure time was $48 \mathrm{hr}$. After this exposure, films were processed in Kodak D19 at $22^{\circ} \mathrm{C}$ for $4 \mathrm{~min}$ and then fixed for $5 \mathrm{~min}$.

Intrathecal injections and behavioral analysis. Intrathecal injections $(5 \mu \mathrm{l})$ into the lumbar region of unanesthetized male CD1 mice (20 to $25 \mathrm{gm}$ ) and analysis of the biting and scratching response were performed as described previously (Hylden and Wilcox, 1981). BN, GRP, or SP (100 pmol; Peninsula Laboratories) or vehicle $(0.01 \mathrm{~N}$ acetic acid in saline, $\mathrm{pH} 3.5$ ) at a concentration of $100 \mathrm{pmol} / 5 \mu \mathrm{l}$ was injected and the number of biting or scratching responses per period was counted. A response was defined as either the nose touching the abdomen or the hindlimb touching the body. The behavioral response was analyzed both quantitatively and qualitatively.

\section{Results}

As shown in Table I, the highest concentrations of BN in all three species were found in the dorsal horn of the cervical spinal cord. In the cat, the dorsal horn dissection corresponds to laminae I to III as described previously (Massari et al., 1983), while in the rat and mouse, some of lamina IV may be included in the dissection. BN concentrations were about 25 times higher in the dorsal horn than in the ventral horn. In the mouse dorsal horn, concentrations of $\mathrm{BN}$ were similar to that in the cat and rat, whereas in the ventral horn, levels were somewhat higher compared to the rat or cat, although these ventral horn concentrations were at the minimal detectable level of the BN RIA.

The results of immunocytochemical studies were consistent with the RIA findings. Immunoreactive fibers were observed in laminae I and II in the cat, rat, and mouse spinal cords (Fig. 1). Few, if any, fibers were found in other regions of the rat and mouse spinal cord. In the cat cord, a number of immunoreactive fibers were observed in lamina $X$ adjacent to the central canal. In general, the staining of spinal cord with $\mathrm{BN}$ antisera was sparse and was much less intense than staining of SP (personal observations). This is consistent with the fact that BN is in much lower concentrations in the spinal cord than in SP. After dorsal root transection, very few BN-immunoreactive fibers were observed in the superficial lamina of the dorsal horn of the spinal cord; however, $\mathrm{BN}$-immunoreactive fibers could still be observed in lamina $\mathrm{X}$ of the cord. Alternate

TABLE I

Distribution of bombesin in the cervical spinal cord ${ }^{a}$

\begin{tabular}{|c|c|c|}
\hline & Dorsal Horn & Ventral Horn \\
\hline & \multicolumn{2}{|c|}{$\mathrm{fmol} / \mu \mathrm{g}$ of protein } \\
\hline Cat & $0.46 \pm 0.05$ & $0.02 \pm 0.001$ \\
\hline Rat & $1.04 \pm 0.18$ & $0.04 \pm 0.005$ \\
\hline Mouse & $0.47 \pm 0.13$ & $0.21 \pm 0.03$ \\
\hline
\end{tabular}

${ }^{a}$ Values are mean $\pm \mathrm{SEM}$. 

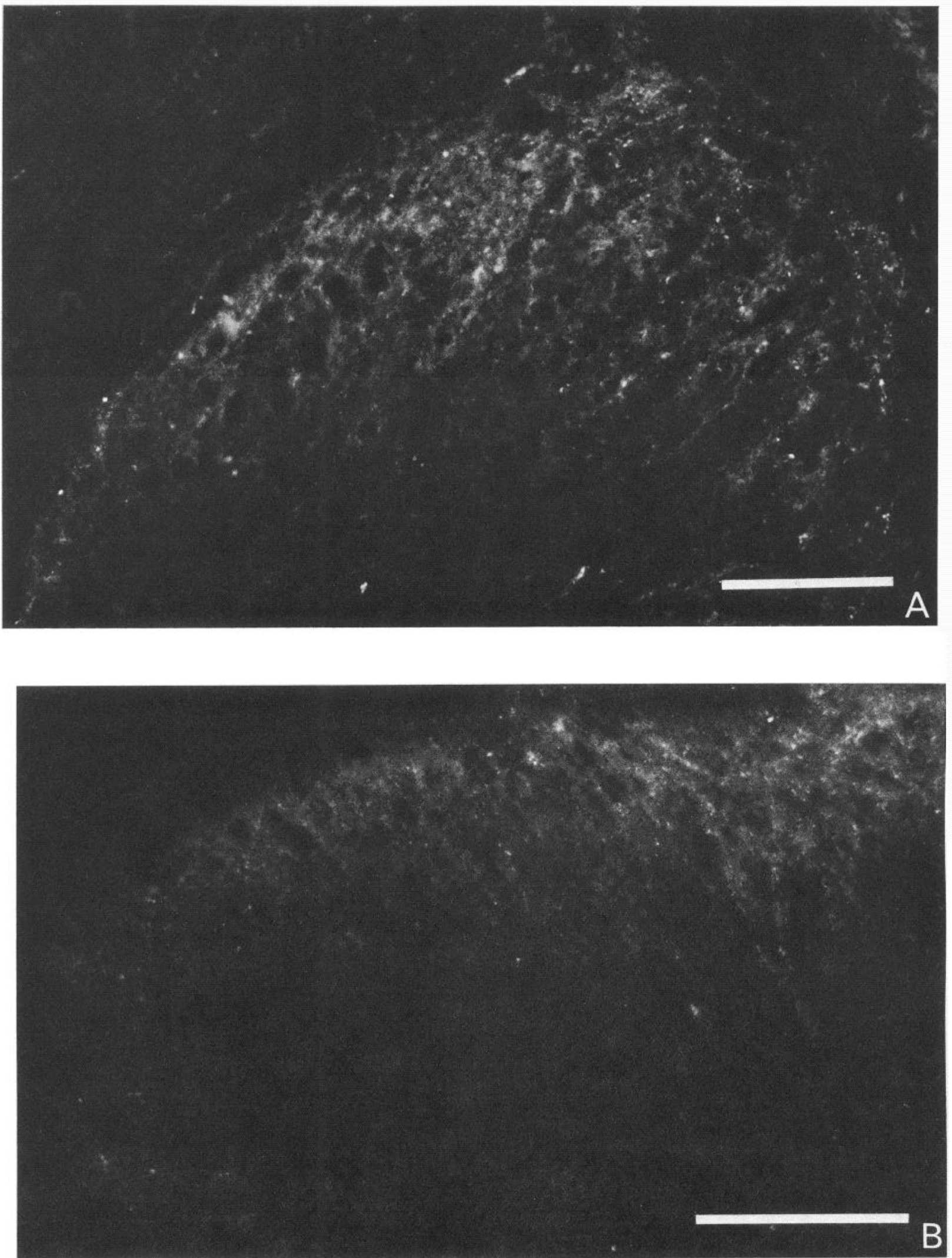

Figure 1. Immunocytochemical localization of $\mathrm{BN}$-immunoreactive fibers in the dorsal horn of the cat thoracic $(A)$ and mouse cervical $(B)$ spinal cord. Bar $=\mu \mathrm{m}$. 



Figure 2. Autoradiographic localization of BN-binding sites in the cat lumbar $(A)$ and rat cervical $(B)$ spinal cord. Bar $=1 \mathrm{~mm}$.

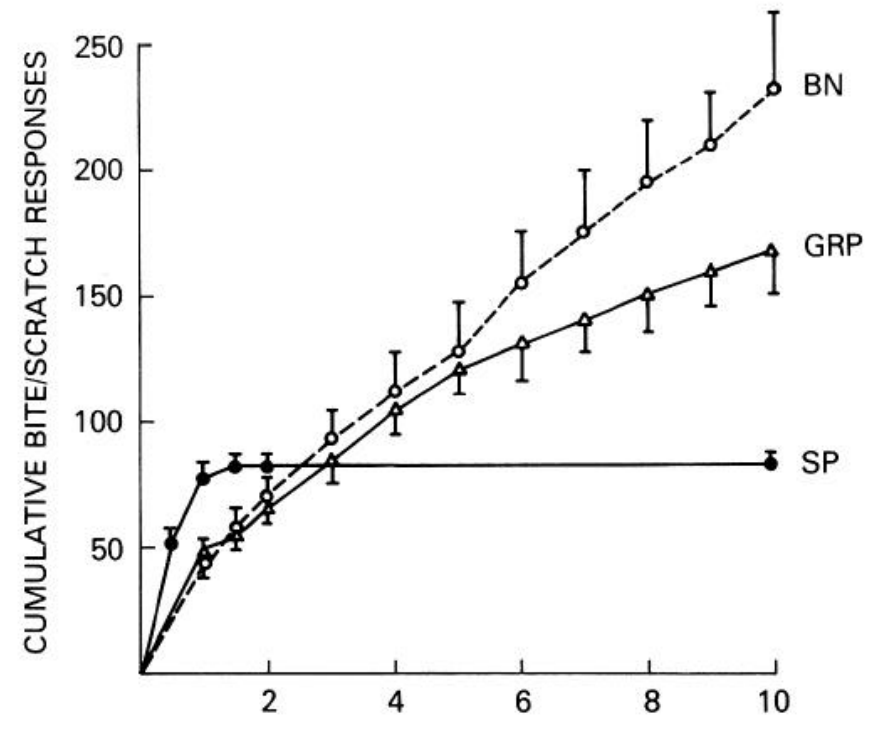

MINUTES AFTER INTRATHECAL INJECTION

Figure 3. Quantitative effects of $100 \mathrm{pmol}$ of BN, GRP, and SP on the bite/scratch response after intrathecal injection.

sections stained for SP also showed the expected decrease after rhizotomy.

The results of the autoradiographic localization of BN-binding sites in the cat and rat are shown in Figure 2. The distribution of $\mathrm{BN}$-binding sites is quite striking. Binding sites can be observed in the superficial laminae of the dorsal hornlaminae I to III and perhaps IV of the dorsal horn; no autoradiographic grains could be observed in the white matter or in the ventral horn. A similar distribution was observed throughout the length of the cat spinal cord and from the cervical to the lumbar cord of the rat and mouse. Neither the pattern nor the intensity of the BN-binding site autoradiography was altered in spinal cord sections from cats that received dorsal rhizotomies 7 days prior to sacrifice.

Intrathecal administration of $\mathrm{BN}, \mathrm{GRP}$, or SP into the lumbar region rapidly induced a vigorous bite/scratch response, as shown quantitatively in Figure 3. Vehicle-injected mice exhibited fewer than 10 responses over the entire 10-min observation period. The major difference between the effects of the peptides was temporal in nature. The durations of action (the time at which half of the injected mice were still responding) of SP, GRP, and $\mathrm{BN}$ were 1,14 , and $120 \mathrm{~min}$, respectively (Fig. 4). There was also a qualitative difference between the actions of the peptides. Although the bite/scratch actions of the peptides appeared similar initially, being directed to the abdominal region, the response to $\mathrm{BN}$ and GRP soon generalized to other parts of the body and came to resemble a vigorous grooming behavior.

\section{Discussion}

The results of immunocytochemical and RIA studies demonstrated that $\mathrm{BN}$ is located in superficial laminae of the spinal cord of the rat, cat, and mouse. Quite low concentrations of BN were detected in other regions of spinal cord. Consistently, the $\mathrm{BN}$-binding sites were also localized only in superficial laminae of the cord. The presence of both $\mathrm{BN}$ and $\mathrm{BN}$ receptors in the dorsal horn of the cord suggested the possibility that BN might be involved in processing of sensory information. Furthermore, the fact that some of the $\mathrm{BN}$ in the dorsal horn is derived from primary sensory afferents (this study and Fuxe et al., 1983; Massari et al., 1983; Panula et al., 1983) indicates that, in some cases, BN may be a sensory neurotransmitter.

The results of studies injecting $\mathrm{BN}$ intrathecally into lumbar spinal cord support the hypothesis that $\mathrm{BN}$ may play a role in sensory processing. The peptide dramatically elicited a stereotypic scratching and grooming response directed at the abdominal region. The fact that the bite/scratch response was directed at the abdominal region is consistent with a lumbar spinal cord innervation from this region. The response was similar to that elicited with SP administration with the exception that the BN effect lasted about 100 times longer than that induced by SP and generalized to other body regions. GRP also induced a similar effect that lasted about 10 times longer than the SP effect. This temporal difference may result from different rates of degradation by peptidases or by different postsynaptic events after different receptor stimulation. It has been demonstrated that BN and SP bind to different receptors (Jensen et al., 1978; Moody et al., 1978; Quirion et al., 1983). The long-term qualitative differences between $\mathrm{SP}$ and $\mathrm{BN}$ or GRP may result from diffusion to other spinal and, perhaps, brain sites.

Previous investigations had demonstrated that, when either $\mathrm{BN}$ or GRP was administered intraventricularly to rats and mice, a stereotypic behavior characterized by grooming and scratching of the face and neck was elicited (Brown et al., 1977, 1980; Katz, 1980; Gmerek and Cowan, 1981; Kulkosky et al., 


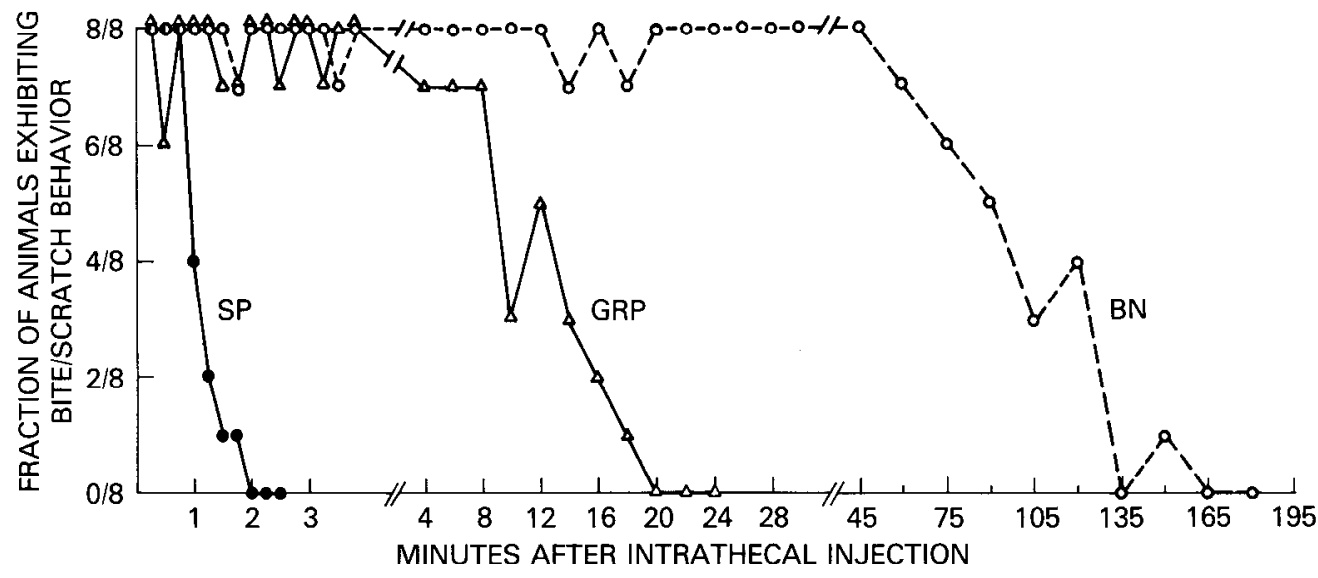

Figure 4. A comparison of the duration of action of $100 \mathrm{pmol}$ of $\mathrm{BN}$ GRP, and SP on the bite/scratch response after intrathecal injection.

1982). Induction of grooming has been reported after the administration of a number of other peptides such as litorin (Kulkosky et al., 1981), eledoisin (Katz, 1980), SP (Katz, 1979), ACTH (Ferrari et al., 1963; Gispen et al., 1975; Gispen and Isaacson, 1981), $\alpha$-melanocyte stimulating hormone (Gispen et al., 1975; O'Donohue et al., 1981), $\beta$-endorphin (Gispen et al., 1976), dynorphin (Zwiers et al., 1981), and caerulein (Jerome et al., 1981). It has been proposed that grooming in rodents is comparable to stress-induced displacement behaviors in humans such as "nail-biting" (Bolles, 1960; Barnett, 1963; Fentress, 1968; Hinde, 1970; Delius et al., 1976; Wiegant and Gispen, 1977; Cohen and Price, 1979; Jolles et al., 1979) or may be induced by a shift in sensitivity to normal stimuli which induce grooming. As intraventricular administration of $\mathrm{BN}$ causes alteration in body temperature (Brown et al., 1977; Tache et al., 1980), the possibility exists that rats increase grooming rates more for thermoregulatory purposes (cf. Kulkosky et al., 1982). An alternative hypothesis is that $\mathrm{BN}$ is involved in primary sensory transmission in the brain as in the spinal cord. Intraventricularly administered BN may cause grooming and scratching by stimulating second-order cranial sensory neurons which mimic a painful or irritating stimulation of the skin of the face and neck region. Consistent with this hypothesis are the recent findings that $\mathrm{BN}$-immunoreactive peptides (Moody et al., 1981a, c; Panula et al., 1982; Fuxe et al., 1983; Chronwall et al., 1984) and receptors (Zarbin et al., 1984) are located in the substantia gelatinosa of the spinal trigeminal nucleus. The spinal trigeminal nucleus also contains SP (Hokfelt et al., 1983) and SP receptors (Quirion et al., 1983; Shults et al., 1984) which also appear to be involved in the processing of primary sensory input from the face and neck (cf. Hokfelt et al., 1983). It is likely that SP and eledoisin may interact on SP receptors in this region to induce scratching and that $\mathrm{BN}, \mathrm{GRP}$, and litorin may interact with trigeminal $\mathrm{BN}$ receptors, as each of these latter peptides are agonists for the $\mathrm{BN}$ receptors (Broccardo et al., 1975; Jensen et al., 1978; Moody et al., 1978).

The mechanism of action of BN modulation of sensory input is unclear, but a number of possibilities are possible. The most likely alternative is that $\mathrm{BN}$, like $\mathrm{SP}$, is a neurotransmitter of primary sensory afferents. This is probable since dorsal rhizotomy decreases the concentration of $\mathrm{BN}$-like peptides in the dorsal horn as determined by immunohistochemistry and RIA in the rat (Panula et al., 1983) and the cat (this study and Massari et al., 1983), respectively. Opioid receptors have been localized on primary sensory afferents to the spinal cord, and it is thought that opiates presynaptically inhibit sensory impulses via axoaxonic synapses (cf. Jessel, 1983). Whether opioid receptors are localized on $\mathrm{BN}$ afferents and can mediate the release of $\mathrm{BN}$ is not known at present. Recent findings (Fuxe et al., 1983) support the suggestion that $\mathrm{BN}$ is contained in the dorsal root ganglion and indicate that $\mathrm{BN}$ and SP are, in fact, often co-localized in primary sensory afferents. Evidence suggesting that $\mathrm{BN}$ and $\mathrm{SP}$ are co-localized in the dorsal horn is surprising in light of the previous findings that the release of $\mathrm{SP}$ but not $\mathrm{BN}$ is induced by capsaicin stimulation of the rat spinal cord (Moody et al., 1981c). In this regard, it is important to note the recent results of Panula et al. (1983) which indicate that $\mathrm{BN}$ and SP are contained in different primary sensory neurons. In addition to the BN contained in primary sensory afferents, there is a proportion of $\mathrm{BN}$ in the dorsal horn that is derived from central neurons (Massari et al., 1983). These central BN-containing neurons could innervate opiate or nonopiate interneurons or secondary sensory neurons. The fact that dorsal rhizotomy does not eliminate $\mathrm{BN}$ binding to the dorsal horn indicates that $\mathrm{BN}$ receptors are not primarily localized on sensory afferents.

In summary, it appears that $\mathrm{BN}$ is contained in both primary sensory afferents and central neurons in laminae I and II of the dorsal horn of the spinal cord. The data also indicate that the dorsal horn contains $\mathrm{BN}$ receptors, since $\mathrm{BN}$-binding sites were located there and $\mathrm{BN}$ pharmacological actions indicative of sensory stimulation could be demonstrated. Further investigation will be required to determine the precise anatomical and physiological relationships between $\mathrm{BN}-$, SP-, and opiatecontaining neurons of the dorsal horn and their roles in mediating the neurotransmission of sensory and nociceptive stimuli.

\section{References}

Andriulli, A., A. Amato, C. Valente, P. Piantino, E. Gaia, and F. Palmas (1983) Dose-related effect of bombesin on serum cationic trypsinosen levels. Digestion 26: 67-72.

Baile, C. A., and M. A. Della-Ferra (1981) Bombesin injected into cerebral ventricles decreases feed intake of sheep. Fed. Proc. 40:308.

Barnett, S. A. (1963) The Rat: A Study in Behavior, Aldine Publishing Co., Chicago.

Barthio, L., P. Holzer, J. Donnerer, and F. Lembeck (1982) Effects of substance $\mathbf{P}$, cholecystokinin octapeptide, bombesin, and neurotensin on the peristaltic reflex of the guinea-pig ileum in the absence and in the presence of atropine. Naunyn Schmiedebergs Arch. Pharmacol. $321: 321-328$.

Bertaccini, G., V. Erspamer, P. Melchiorri, and N. Sopranzi (1974a) Gastrin release by bombesin in the dog. Br. J. Pharmacol. 52: 219225.

Bertaccini, G., M. Impicceatore, E. Molina, and L. Zappia (1974b) Action of bombesin on human gastrointestinal motility. Rend. Gastro-Enterol. 6: 45-51.

Bicknell, R. J., and C. Chapman (1983) Bombesin stimulates growth hormone secretion from cultured bovine pituitary cells. Neuroendo crinology 36: 33-38.

Bolles, R. C. (1960) Grooming behavior in the rat. J. Comp. Physiol. Psychol. 53: 306-310.

Broccardo, M., G. F. Erspamer, P. Melchiorri, and L. Negri (1975) 
Relative potency of bombesin-like peptides. Br. J. Pharmacol. 55: 221-227.

Brown, M., J. Rivier, and W. Vale (1977). Bombesin: Potent effects on thermoregulation in the rat. Science 196: 998-1000.

Brown, M., R. Allen, J. Villareal, J. Rivier, and W. Vale (1978) Bombesin-like activity: Radioimmunological assessment in biological tissues. Life Sci. 23: 2721-2728.

Brown, M., Y. Tache, and E. Fisher (1979) Central nervous system action of bombesin: Mechanism to induce hyperglycemia. Endocrinology 105: 660-665.

Brown, M., W. Marki, and J. Rivier (1980) Is gastrin releasing peptide mammalian bombesin? Life Sci. 27: 125-128.

Brown, M. R., and W. W. Vale (1976) Effects of neurotensin and substance $\mathrm{P}$ on glucoregulators. Endocrinology 98: 819-822.

Buffa, R. T., I. Solovieva, R. Fiocca, S. Giorgino, G. Rindi, E. Solcia, T. Mochizuchi, C. Yanaihara, and N. Yanaihara (1982) Localization of bombesin and GRP (gastrin releasing peptide) sequences in gut nerves or endocrine cells. Histochemistry 76: 457-467.

Caprilli, R., P. Melchiorri, G. Improta, P. Vernia, and G. Frieri (1975) Effects of bombesin and bombesin-like peptides on gastrointestinal myoelectric activity. Gastroenterology 68: 1228-1235.

Chronwall, B., T. W. Moody, J. J. Pisano, and T. L. O'Donohue (1984) Distribution of ranatensin and bombesin immunoreactive neurons in the rat brain. Brain Res., in press.

Cohen, J. A., and E. O. Price (1979) Grooming in the Norway rat: Displacement aclivity or "boundary shift"? Behav. Neurol. Biol. 26. $177-188$.

Coons, A. H. (1958) Fluorescent antibody methods. In General Cytochemical Methods, J. F. Danielli, ed., pp. 399-422, Academic Press, Inc., New York

Cutz, E., W. Chan, and N. S. Track (1981) Bombesin, calcitonin and leu-enkephalin immunoreactivity in endocrine cells of human lung. Experientia 37: 765-767.

Davison, J. S. (1983) Bombesin effects on canine gastric muscle. Am. J. Physiol. 244: G569-G570.

Delius, J. D., B. Craig, and C. Chaudoir (1976) Adrenocorticotropic hormone, glucose and displacement at activities in pigeons. Z. Tierpsychol. 40: 183-193.

Dockray, C. J., C. Vaillant, and J. H. Walsh (1979) The neuronal origin of bombesin-like immunoreactivity in the rat gastrointestinal tract. Neuroscience 4: 1561-1568.

Erisman, M. D., R. I. Linnoile, O. Hernandez, R. P. DiAugustine, and L. H. Lazarus (1982) Human lung small-cell carcinoma contains bombesin. Proc. Natl Acad. Sci. U. S. A. 79: 2379-2383.

Erspamer, V., G. Improta, P. Melchiorri, and N. Sopranzi (1974) Evidence of cholecystokinin release by bombesin in the dog. $\mathrm{Br}$. J. Pharmacol. 52: 227-232.

Erspamer, V., P. Melchiorri, M. Broccardo, G. F. Erspamer, P. Falaschi, G. Improote, L. Negri, and T. Renda (1981) The brain-gut triangle: New peptides. Peptides (Fayetteville) 2 (Suppl. 2): 7-16.

Fentress, J. C. (1968) Interrupted ongoing behavior in two species of vole (Microtus agretis and Clethrionomus brittanicus). I. Response as a function of preceding activity and the context of an apparently "irrelevant" motor pattern. Anim. Behav. 16: 135-153.

Ferrari, W., G. L. Gessa, and L. Vargiu (1963) Behavioral effects induced by intracisternally injected ACTH and MSH. Ann. N. Y. Acad. Sci. 104: 330-345.

Furness, J. B., M. Costa, R. Murphy, A. M. Beardsley, J. R. Oliver, I. J. Llewellyn-Smith, R. L. Eskay, A. A. Shulkes, T. W. Moody, and D. K. Meyer (1982) Detection and characterisation of neurotransmitters, particularly peptides, in the gastrointestinal tract. Scand. J. Gastroenterol. (Suppl). 71: 61-70.

Fuxe, K., L. F. Agnati, T. F. McDonald, V. Locatelli, T. Hokfelt, C. -J. Dalsgaard, N. Battistini, N. Yanaihara, V. Mutt, and A. C. Cuello (1983) Immunohistochemical indications of gastrin-releasing peptide-bombesin-like immunoreactivity in the nervous system of the rat. Codistribution with substance P-like immunoreactive nerve terminal systems and coexistence with substance P-like immunoreactivity in dorsal root ganglion cell bodies. Neurosci. Lett. 37: 17-22.

Gibbs, J., and D. J. Fauser (1981) Bombesin works at both ends. Soc. Neurosci. Abstr. 7: 380.

Gibbs, J., D. J. Fauser, E. P. Rowe, B. J. Rolls, E. T. Rolls, and S. P. Maddison (1979) Bombesin suppresses feeding in rats. Nature 282: 208-210.
Gispen, W. H., and R. L. Isaacson (1981) $\Lambda \mathrm{CTH}$-induced excessive grooming in the rat. Pharmacol. Ther. 12: 209-246.

Gispen, W. H., V. M. Wiegant, H. M. Greven, and D. de Wied (1975) The induction of excessive grooming in the rat by intraventricular application of peptides derived from ACTH: Structure-activity studies. Life Sci. 17: 645-652.

Gispen, W. H., V. M. Wiegant, A. F. Bradbury, E. C. Hulme, D. G. Smyth, C. R. Snell, and D. de Wied (1976) Induction of excessive grooming in the rat by fragments of lipotropin. Nature 264: 794-795.

Gmerek, D. E., and A. Cowan (1981) Tolerance and cross-tolerance studies on the grooming and shaking effect of ACTH (1-24), bombesin and RX 336-M. Fed. Proc. 40: 274.

Hinde, R. A. (1970) Animal Behavior. A Synthesis of Etiology and Comparative Psychology, McGraw-Hill Book Co, New York.

Hirschowitz, B. I., and E. Molina (1983) Relation of gastric acid and pepsin secretion to serum gastrin levels in dogs given bombesin and gastrin-17. Am. J. Physiol. 244: G546-G551.

Hokfelt, T., A. Ljungdahl, L. Terenius, R. Elde, and G. Nilsson (1983) Immunohistochemical analysis of peptide pathways possibly related to pain and analgesia: Enkephalin and substance P. Proc. Natl. Acad. Sci. U. S. A. 74: $3081-3085$.

Hsaio, S., and R. Spencer (1983) Analysis of licking responses in rats: Effects of cholecystokinin and bombesin. Behav. Neurosci. 97: 234245

Hylden, J. L. K., and G. Wilcox (1981) Intrathecal substance P elicits a caudally-directed biting and scratching behavior in mice. Brain Res. 217: 212-215.

Jensen, R. T., T. Moody, C. Pert, J. F. Rivier, and J. D. Gardner (1978) Interaction of bombesin and itorin with specific membrane receptors on pancreatic acinar cells. Proc. Natl. Acad. Sci. U. S. A. 75: 61396143.

Jerome, C., P. Kulkosky, K. Simansky, and G. P. Smith (1981) Peripheral caerulein, like CCK, acts in the abdomen and not in the brain to produce satiety in rats. Soc. Neurosci. Abstr. 7: 852.

Jessel, T. M. (1983) Substance P in the Nervous System. In Handbook of Psychopharmacology, Vol. 16: pp. 1-106. L. L. Iverson, S. D. Iverson, and S. H. Snyder, eds. Vol. 16, pp. 1-106, Plenum Press, New York.

Jolles, J., J. Rompa-Barendregt, and W. H. Gispen (1979) Novelty and grooming behavior in the rat. Behav. Neurol. Biol. 25: 563-572.

Katz, R. J. (1979) Central injection of substance $\mathbf{P}$ elicits grooming behavior and motor inhibition in mice. Neurosci. Lett. 12: 133-136.

Katz, R. (1980) Grooming elicited by intracerebroventricular bombesin and eledoisin in the mouse. Neuropharmacology 19: 143-146.

Kulkosky, P. J., D. J. Fanser, and J. Gibbs (1981) Litocin suppresses food intake in rats. Soc. Neurosci. Abstr. 7: 852.

Kulkowsky, P. J., J. Gibbs, and G. P. Smith (1982) Behavioral effects of bombesin adninistration in rats. Physiol. Behav. 28: 505-512.

Loren, I., A. Bjorklund, B. Falck, and O. Lindvall (1980) The aluminum-formaldehyde (ALFA) histofluorescence method for improved visualization of catecholamines and indoleamines. I. A detailed account of the methodology for central nervous tissue using paraffin, cryostat in vibrotome sections. J. Neurosci. Methods. 2: 277-300.

Lowry, O. H., N. J. Rosebrough, A. L. Farr, and R. J. Randall (1951) Protein measurement with the Folin phenol reagent. J. Biol. Chem. 193: 265-275.

Martin, C. F., and J. Gibbs (1980) Bombesin elicits satiety in sham feeding rats. Peptides 1: 131-134.

Massari, V. J., Y. Tizabi, C. H. Park, T. W. Moody, C. J. Helke, and T. L. O'Donohue (1983) Distribution and origin of bombesin, substance $\mathrm{P}$ and somatostatin in rat spinal cord. Peptides 4: 673-681.

McDonald, 'I'. J., H. Jornvall, G. Nilsson, M. Vagne, M. Ghatei, S. R. Bloom, and V. Mutt (1979) Characterization of a gastrin releasing peptide from porcine non-antral gastric tissue. Biochem. Biophys. Res. Commun. 90: 227-233.

McDonald, T. J., M. A. Ghatei, S. R. Bloom, T. E. Adrian, T. Mochizuki, C. Yanaihara, and N. Yanaihara (1983) Dose-response comparisons of canine plasma gastroenteropancreatic hormone responses to bombesin and the porcine gastrin-releasing peptide (GRP). Regul. Pept. 5: 125-137.

Minamino, N., K. Kangawa, and H. Matsuo (1983) Neuromedin B: A novel bombesin-like peptide identified in porcine spinal cord. Biochem: Biophys. Res. Commun. 114: 541-548.

Moody, T. W., and C. B. Pert (1979) Bombesin-like peptides in rat 
brain: Quantitation and biochemical characterization. Riochem. Biophys. Res. Commun. 90: 7-14.

Moody, T. W., C. B. Pert, J. Rivier, and M. R. Brown (1978) Bombesin: Specific binding to rat brain membranes. Proc. Natl. Acad. Sci. U. S. A. $75: 5372-5376$

Moody, T. W., N. B. Thoa, T. L. O'Donohue, and C. B. Pert (1980) Bombesin-like peptides in rat brain: Localization in synaptosomes and release from hypothalamic slices. Life Sci. 26: 1707-1712.

Moody, T. W., T. L. O'Donohue, and D. M. Jacobowitz (1981a) Biochemical localization and characterization of bombesin-like peptides in discrete regions of rat brain. Peptides 2: 75-89.

Moody, T. W., C. B. Pert, A. F. Gazdar, D. W. Carney, and J. D. Minna (1981b) High levels of intracellular bombesin characterize human small-cell lung carcinoma. Science 214: 1246-1248.

Moody, T. W., N. B. Thoa, T. L. O'Donohue, and D. M. Jacobowitz (1981c) Bombesin-like peptides in rat spinal cord: Biochemical characterization, localization and mechanism of release. Life Sci. 29 2273-2279.

Moody, T. W., E. K. Russell, T. L. O'Donohue, C. D. Linden, and A F. Gazdar (1983) Bombesin-like peptides in small cell lung cancer: Biochemical characterization and secretion from a cell line. Life Sci 32: 487-493.

Morley, J. E., and A. S. Levine (1981) Bombesin inhibits stress-induced eating. Pharmacol. Biochem. Behav. 14: 149-151.

O'Donohue, T. L., G. E. Handelmann, T. Chaconas, R. L. Miller, and D. M. Jacobowitz (1981) Evidence that $\mathrm{N}$-acetylation regulates the behavioral activity of $\alpha$-MSH in the rat and human central nervous system. Peptides 2: 333-344.

Panula, P., H. Y. Yang, and E. Costa (1982) Neuronal location of the bombesin-like immunoreactivity in the central nervous system of the rat. Regul. Pept. 4: 275-283.

Panula, P., M. Hadjiconstantinou, H. Y. Yang, and E. Costa (1983) Immunohistochemical localization of bombesin/gastrin-releasing peptide and substance $\mathbf{P}$ in primary sensory neurons. J. Neurosci. 3 : 2021-2029.

Pert, A., T. W. Moody, C. B. Pert, L. A. Dewald, and J. River (1980) Bombesin: Receptor distribution in brain and effects on nociception and locomotor activity. Brain Res. 193: 209-220.

Phillis, J. W., and J. R. Kirkpatrick (1979) Actions of various gastrointestinal peptides on the isolated amphibian spinal cord. Can. J. Physiol. Pharmacol. 57: 887-899.

Phillis, J. W., and J. J. Limacher (1974) Excitation of cerebral cortical neurons by various polypeptides. Exp. Neurol. 43: 414-423.

Pittman, Q. J., Y. Tache, and M. R. Brown (1980) Bombesin acts in preoptic area to produce hypothermia in rats. Life Sci. 26: 725-730.

Polak, J. M., and S. R. Bloom (1982) Regulatory peptides and neuron specific enolase in the respiratory tract of man and other mammals. Exp. Lung Res. 3: 313-328.

Polak, J. M., S. R. Bloom, S. Hobbs, S. Solcia, and A.G. Pearse (1976) Distribution of a bombesin-like peptide in human gastrointestinal tract. Lancet 1: 1109-1110.

Quirion, R., C. W. Shults, T. W. Moody, C. B. Pert, T. N. Chase, and T. L. O'Donohue (1983) Autoradiographic distribution of substance $P$ receptors in rat central nervous system. Nature 303: 714-716.

Rivier, C., J. Rivier, and W. Vale (1978) The effects of bombesin and related peptides on prolactin and growth hormone secretion in the rat. Endocrinology 102: 519-527.

Rosengurt, E., and J. Sinnett-Smith (1983) Bombesin stimulation of DNA synthesis and cell division in cultures of Swiss 3T3 cells. Proc. Natl. Acad. Sci. U. S. A. 80: 2936-2940.

Roth, K. A., E. Weber, and J. D. Barchas (1982) Distribution of gastrin releasing peptide-bombesin-like immunostaining in rat brain. Brain Res. 251: 277-282.

Schultzberg, M. (1983) Bombesin-like immunoreactivity in sympathetic ganglia. Neuroscience 8: 363-374.

Shults, C. W., R. Quirion, B. Chronwall, T. N. Chase, and T. C. O'Donohue (1984) A comparison of the distribution of substance $P$ and substance $\mathrm{P}$ receptors in the rat central nervous system. Peptides, in press.
Smith, G. P., C. Jerome, and J. Gibbs (1981) Abdominal vagotomy does not block the satiety effect of bombesin in the rat. Peptides 2: 409 411.

Sorenson, G. D., S. R. Bloom, M. A. Ghatei, S. A. Del Prete, C. C. Cate, and O. S. Pettengill (1982) Bombesin production by human small cell carcinoma of the lung. Regul. Pept. 4: 59-66.

Stein, L. J., and S. C. Woods (1981) Cholecystokinin and bombesin act independently to decrease food intake in the rat. Peptides 2: 431436.

Suzue, I., N. Yanaihara, and M. Otsuka (1981) Actions of vasopressin, gastrin releasing peptide and other peptides on neurons on newborn rat spinal cord in vitro. Neurosci. Lett. 26: 137-142.

Tache, Y., and M. Brown (1982) Bombesin: Central nervous system action to increase gastric mucus in rats. Gastroenterology 83: 75-80.

Tache, Y., and M. Brown (1982) On the role of bombesin in homeostasis. Trends Neurosci. 5: 1-3.

Tache, Y., and R. Collu (1982) CNS mediated inhibition of gastric secretion by bombesin: independence from interaction with brain catecholaminergic and serotoninergic pathways and pituitary hormones. Regul. Pept. 3: 51-59.

Tache, Y., M. Brown, and R. Collu (1979) Effects of neuropeptides on adenohypophyseal hormone response with acute stress in male rats. Endocrinology 105: 220-224.

Tache, Y., Q. Pittman, and M. Brown (1980) Bombesin-induced poikilothermy in rats. Brain Res. 188: 525-530.

Tache, Y., W. Vale, J. Rivier, and M. Brown (1981) Brain regulation of gastric acid secretion in rats by neurogastrointestinal peptides. Peptides 2 (Suppl. 2): 51-55.

Tartara, A., P. Bo, and F. Savoldi (1982) Neuropeptides and cerebral electric activity in rabbits. Peptides 3: 125-127.

Tepperman, B. L., and M. D. Evered (1980) Gastrin injected into the lateral hypothalamus stimulates secretion of gastrin acid in rats. Science 209: 1142-1143.

Track, N. S., and E. Cutz (1982) Bombesin-like immunoreactivity in developing human lung. LIfe Sci. 30: 1553-1556.

Tsutsumi, Y., R. Y. Osamura, K. Watanabe, and N. Yanaihara (1983) Immunohistochemical studies on gastrin-releasing peptide- and adrenocorticotropic hormone-containing cells in the human lung. Lab. Invest. 48: 623-632.

Walsh, J. H., H. C. Wang, and G. J. Dockray (1979) Bombesin-like peptides in mammals. Fed. Proc. 38: 2315-2319.

West, D. B., R. H. Williams, D. J. Braget, and S. J. Woods (1982) Bombesin reduces food intake of normal and hypothalamically obese rats and lowers body weight when given chronically. Peptides 3: 6167.

Westendorf, J. M., and A. Schonbrunn (1982) Bombesin stimulates prolactin and growth hormone release by pituitary cells in culture. Endocrinology 110: 352-358.

Wharton, J., J. M. Polak, S. R. Bloom, M. A. Ghatea, E. Solcia, M. R. Brown, and A. G. E. Pearse (1978) Bombesin-like immunoactivity in the lung. Nature 273: 769-770.

Wiegant, V. M., and W. H. Gispen (1977) ACTH-induced excessive grooming in the rat: Latent activity of ACTH 4-10. Behav. Biol. 19: $554-558$.

Wolf, S. S., T. W. Moody, T. L. O'Donohue, M. A. Zarbin, and M. J. Kuhar (1983) Autoradiographic visualization of rat brain binding sites for bombesin-like peptides. Eur. J. Pharmacol. 87: 163-164.

Wood, S. M., J. R. Wood, M. A. Ghatei, Y. C. Lee, D. O. Shaughnessy, and S. R. Bloom (1981) Bombesin, somatostatin and neurotensinlike immunoreactivity in bronchial carcinoma. J. Clin. Endocrinol. Metab. 53: 1310-1312.

Yanaihara, N., C. Yanaihara, T. Mochizuki, K. Iwahara, T. Fujita, and T. Iwanaga (1981) Immunoreactive GRP. Peptides 2 (Suppl. 2): 185191.

Zarbin, M. Z., M. J. Kuhar, T. L. O'Donohue, S. S. Wolf, and T. W. Moody (1984) Autoradiographic localization of ( ${ }^{125}$ I-tyr) bombesin binding sites in rat brain. Neuroscience, in press.

Zwiers, H., V. J. Aloyo, and W. H. Gispen (1981) Behavioral and neurochemical effects of the new opioid peptide dynorphin-(1-13): Comparison with other neuropeptides. Life Sci. 28: 2545-2551. 